\title{
The Effects of Initial Cell Density on the Growth and Proliferation of the Potentially Toxic Cyanobacterium Microcystis aeruginosa
}

\author{
Robert M. Dunn' ${ }^{1,2}$, Kalina M. Manoylov ${ }^{*}$ \\ ${ }^{1}$ Department of Biological and Environmental Sciences, Georgia College \& State University, \\ Milledgeville, GA, USA \\ ${ }^{2}$ Geosyntec Consultants, Kennesaw, GA, USA \\ Email:rdunn@Geosyntec.com, "kalina.manoylov@gcsu.edu
}

Received 7 June 2016; accepted 23 August 2016; published 26 August 2016

Copyright (C) 2016 by authors and Scientific Research Publishing Inc.

This work is licensed under the Creative Commons Attribution International License (CC BY).

http://creativecommons.org/licenses/by/4.0/

(c) (i) Open Access

\begin{abstract}
Increasing input of nutrients is leading to significant eutrophication in aquatic systems across the globe. Toxin production in those blooms is correlated with high cell density. A study was done to investigate the effects of initial cell density on the growth rate of the potentially toxic cyanobacterium Microcystis aeruginosa, in unfiltered lake water as well a common algal growth medium under laboratory conditions. Five treatments were established in the laboratory varying the initial cell density of M. aeruginosa and the growth medium. Unfiltered lake water was inoculated with a low, medium, and high initial cell density and Bold's medium was inoculated with low and high initial cell densities. There was a significant difference in final cell density between the lake water treatments with the high inoculum of cell treatment reaching the highest final cell density. There was also a significant difference in final cell density between the Bold's medium treatments. These results indicate there is a relationship between initial cell density of $M$. aeruginosa and final cell density, however, the results are similar when nutrients are available. Diverse algal communities can keep toxin producing algae in low density therefore precluding the need of toxin production.
\end{abstract}

\section{Keywords}

Algae, Toxins, Algal Growth, Algal Density

\footnotetext{
${ }^{*}$ Corresponding author.
}

How to cite this paper: Dunn, R.M. and Manoylov, K.M. (2016) The Effects of Initial Cell Density on the Growth and Proliferation of the Potentially Toxic Cyanobacterium Microcystis aeruginosa. Journal of Environmental Protection, 7, $1210-1220$. http://dx.doi.org/10.4236/jep.2016.79108 


\section{Introduction}

Rapid growth and acceleration of phytoplankton biomass, usually associated with eutrophication, is commonly termed as an algal bloom [1] [2]. Algal blooms effect the environment and humans in a variety of ways including the potential production of toxins that can affect humans and other biota [3]. Algal blooms can also reduce nutrients, decrease the photic zone, and deplete dissolved oxygen causing hypoxia or anoxia [4] [5], creating an environment that is not suitable for surrounding biota. These blooms form unsightly scums in surface water, reducing the aesthetic and recreational value of effected systems.

There are numerous phyla of phytoplankton that can form blooms including Chlorophyta, Dinophyta, Cryptophyta, Chrysophyta, and Cyanobacteria. The most widespread and problematic phylum that blooms in freshwater systems is cyanobacteria [1]. Cyanobacteria have unique adaptations given their long evolutionary history including the ability to take up phosphorous in excess and store it for use in conditions where phosphorous is limited [6]. These unique adaptations allow cyanobacteria to proliferate in nutrient enriched and nutrient deficient conditions making them the most common nuisance alga in freshwater systems worldwide [1]. Given their long evolutionary history, production of toxins by cyanobacteria predated any possible grazers and some of these toxins are thought to be involved in a protective role in the oxidative stress response of cyanobacteria [7].

Cyanobacteria blooms are extremely concerning because numerous species are capable of producing a range of noxious compounds and toxins [8] and in Europe, Asia and America roughly $40 \%$ of lakes and reservoirs are now eutrophic [9], creating conditions favorable for cyanobacterial cell proliferation. It is estimated that 25 to 75 percent of cyanobacterial blooms are toxic [10]. Toxins produced by cyanobacteria during blooms have been linked to numerous health hazards in humans and animals including liver disease, cancers, and deaths [11]-[13]. Cyanotoxins are a diverse group of compounds with regards to their chemical structure as well as their biological effect. The increasing occurrence and intensity of cyanobacterial blooms, along with the myriad of potential toxins has created an urgent need for management and regulation of cyanobacteria growth in aquatic systems.

There is an increased abundance of cyanobacterial blooms globally, specifically blooms of the potentially toxic, colony-forming genus Microcystis [12]. The worldwide distribution of cyanobacterial blooms has not been coupled with research to understand bloom dynamics and the mechanisms underlying their formation remain poorly understood [14]. The difficulty in field studies is the existence and often co-existence of toxic and non-toxic strains of the same species within a genus that are morphologically and taxonomically similar [15]. Field experiments need to be coupled with laboratory experiments to better understand the dynamics leading to the proliferation of Microcystis populations.

This experimental study aims to investigate the effects of initial cell density on the growth rate of the potentially toxic cyanobacteria $M$. aeruginosa, in unfiltered lake water as well as common algal growth medium under laboratory conditions. The unfiltered lake water replicates natural field conditions and growth of M. aeruginosa in natural conditions from lake water can be affected by competition amongst co-occurring taxa. Wood et al. [16] demonstrated a marked increase in Microcystis cells to densities, which are already high, would cause a significant increase in Microcystis cell density and an increase in microcystin quota. Such results suggest that the initial cell density of $M$. aeruginosa will have an effect on the growth and proliferation of $M$. aeruginosa cells in natural conditions. The growth medium eliminates competitive pressures and replicates optimal conditions for growth of M. aeruginosa, however, a drawback of the growth medium is the lack of replication of natural conditions thus making it difficult to draw comparisons between lab results and field conditions. Low initial cell density of $M$. aeruginosa will reduce the growth of M. aeruginosa when compared to higher cell densities in both the unfiltered lake water and the common algal growth medium despite the lack of competitive pressures in the algal growth medium.

\section{Materials and Methods}

\subsection{Cultures}

Four cultures of Microcystis aeruginosa Kützing were obtained from the culture Collection of Algae at the University of Texas at Austin (UTEX 2061, UTEX 2063, UTEX 2385, UTEX 2386). All cultures were observed under $400 \times$ magnification to ensure the integrity of each culture and confirm taxonomic parameters. Images were taken and any discrepancies within the culture were documented. Cell density of each culture was calculated by conducting 100 cell counts on a Palmer-Maloney counting chamber (Thomas Scientific, \#9853N10). The average biovolume for each culture was calculated by measuring at least 100 specimens and approximating 
the shape of each cell to a sphere [17].

\subsection{Experimental Medium}

Microcystis aeruginosa Kützing was inoculated in two different media. The growth media used were Bold Modified Basal Freshwater Nutrient Solution (Sigma-Aldrich, St. Louis, MO) and unfiltered water from Lake Sinclair, Georgia. On March 24, 2014, $500 \mathrm{~mL}$ of water from Lake Sinclair, Georgia was taken from the surface of the lake and placed into a brown Nalgene bottle to deprive the plankton community of light and prevent further growth and reproduction. The sample was homogenized by shaking the sample to ensure an even distribution of the phytoplankton and zooplankton community. Known volume of the lake water was observed under $400 \times$ magnification to document the phytoplankton and zooplankton community. $0.1 \mathrm{~mL}$ of lake water was placed into a Palmer-Maloney counting chamber and a minimum of 250 live units were counted and identified to the lowest taxonomic level. Following completion of experimental setup, the remaining volume of lake water was preserved using $20 \%$ formalin by volume.

Bold Modified Basal Freshwater Nutrient Solution (Bold's) is a common algal growth medium used in experimental work with M. aeruginosa [18]. A stock solution of Bolds medium was created following standard protocol (Sigma Aldrich, \#B5282). The resulting stock medium solution contains $1000 \mathrm{mg} / \mathrm{L}$ nitrogen and phosphorous.

\subsection{Experimental Design}

Five different treatments and a control group in triplicates were created using $2 \mathrm{~mL}$ glass vials. The control treatment consisted of $2 \mathrm{~mL}$ of lake water only. All treatments consisted of $1 \mathrm{~mL}$ of the medium and $1 \mathrm{~mL}$ of UTEX 2385. Treatments differed by the initial $M$. aeruginosa cell density inoculation and the medium with which the cells were placed in. Three treatments consisted of M. aeruginosa and unfiltered lake water and these were termed low + lake, medium + lake, and high + lake, indicating the cell density and the medium used. Two treatments consisted of M. aeruginosa and Bolds freshwater medium and were termed low + Bolds and high + Bolds, indicating the cell density and the medium used (Table 1).

The low treatments were inoculated with a cell density of 1069 cells. The medium treatment was inoculated with triple number of cells and the high treatments were inoculated with six times higher number of cells. An extensive literature review was done to determine these densities and they are similar to densities used in other experimental work. Each inoculate was $1 \mathrm{~mL}$ of culture respectively (Table 1). A total of 15 vials were inoculated per treatment to allow for sampling of 3 vials on each sampling day for a total of 15 days. The experiment was conducted in an incubator (Percival Scientific Inc., I-36VL, Perry, IA) under continuous light exposure at $22^{\circ} \mathrm{C}$.

\subsection{Sample Analysis}

Three vials of each treatment were removed at random on each sampling day for cell counting. Sampling was conducted every 3 days for a 15-day period. Counting was done on day 0, 3, 6, 9, 12, and 15 respectively. On each sampling day, each sample was preserved using $10 \%$ by volume formaldehyde. Each vial was shaken and

Table 1. Description and names of the experimental treatments in both runs ( $\mathrm{LW}=$ lake water). Initial cells/mL inoculated Microcystis aeruginosa.

\begin{tabular}{|c|c|c|c|}
\hline \multirow{2}{*}{ Treatment } & \multicolumn{2}{|c|}{ Run 1} & \multirow{2}{*}{$\begin{array}{c}\text { Run } 2 \\
\text { Initial Density }\end{array}$} \\
\hline & Medium & Initial Density & \\
\hline Control & Unfiltered LW & 0 & 0 \\
\hline Low + Lake & Unfiltered LW & 1069.00 & 1064.36 \\
\hline Med + Lake & Unfiltered LW & 3208.00 & 3345.15 \\
\hline High + Lake & Unfiltered LW & 6417.00 & 7204.93 \\
\hline Low + Bolds & Bolds & 1069.00 & 1064.36 \\
\hline High + Bolds & Bolds & 6417.00 & 7204.93 \\
\hline
\end{tabular}


$0.1 \mathrm{~mL}$ was removed and placed onto a Palmer-Maloney counting chamber. A minimum of 100-cell counts at $400 \times$ magnification was conducted to determine the density of each sample. Biovolume was calculated by approximating the shape of each cell to a sphere [17] and taking the average of 100 cells. Biomass was then calculated by multiplying cell density by the average cell biovolume. Averages for cell density and biomass were calculated for each treatment on each sampling day.

The growth rate, defined as the change in growth over time, for each treatment was determined by dividing the difference between the average cell densities of two sampling events by the amount of days between the sampling events, three. The growth rate was then plotted over time to determine the difference in growth rate over time between each treatment. Increase in average biomass throughout time for each treatment was determined by plotting the average biomass over time.

A one-way ANOVA was conducted to compare the effect of low and high initial cell density on the final cell density in the high + lake, medium + lake, and low + lake treatments and to compare the difference in final cell density between the two types of medium.

\subsection{Experimental Design Run 2}

In this run, the lake water to be used as medium was collected from the same location on September 20, 2014 following the same protocol as described above. Instead of using $2 \mathrm{~mL}$ glass vials, this run was conducted using $4 \mathrm{~mL}$ glass vials to allow for a larger amount of medium and more available volume when preserving samples. Each treatment was inoculated with $2 \mathrm{~mL}$ of medium and 1mL of UTEX 2385 of varying densities. The densities from the first run were replicated as close as possible by diluting the stock culture. The control treatment was consisted of $3 \mathrm{~mL}$ of lake water only. The low initial cell densities were inoculated with 1064 cells. The medium treatment was inoculated with triple number of cells and the high treatments were inoculated with seven times higher number of cells (Table 1). All sample analysis and protocols were replicated from the first experimental run.

\section{Results}

The lake water collected in March contained numerous genera representing specimens from Chlorophyta (green algae), Euglenophyta, Bacillariophyceae (diatoms), and Cyanobacteria. The community was dominated by diatoms, representing over 50 percent of the community. Cyanobacteria were the second most abundant community observed in Lake Sinclair in March representing 25 percent of the community. Zooplankton was also observed in the natural community of Lake Sinclair including Bosmina and Daphnia.

Cell density of Microcystis aeruginosa increased for each treatment during the course of the 15-day experiment and there was no M. aeruginosa observed in the control group during either experiment runs. In experimental run 1, treatments inoculated with a low initial cell density, low + lake and low + Bolds, reached final cell densities of 495,894 \pm 79,440 cells/mL and 408,646 \pm 14,441 cells/mL, respectively In experimental run two, the treatments inoculated with a low initial cell density, low + lake and low + Bolds, reached lower final cell densities of $9504 \pm 113$ cells $/ \mathrm{mL}$ and $8682 \pm 95$ cells/mL, respectively. The lake water treatment inoculated with a medium cell density of $M$. aeruginosa reached a final cell density of 850,581 \pm 150 cells/mL in the first run and $24,217 \pm 752$ cells/mL in the second run. The high initial cell density treatments in run 1 , high + lake and high + Bolds, reached final cell densities of 1,836,257 \pm 198,928 cells/mL and 1,616,927 $\pm 23,374$ cells/mL, respectively (Table 2). In the second run, the treatments inoculated with a high initial cell density, high + lake and high + Bolds, reached lower final cell densities of 35,635 \pm 1636 cells/mL and 32,137 \pm 1329 cells/mL, respectively (Table 2).

Biomass of $M$. aeruginosa increased throughout the course of both experimental runs, with the treatments inoculated with the highest cell density, high + lake and high + Bolds, reaching the highest biomass on day 15 . The high + lake treatment in run one had the highest final average biomass of 41,201,789 $\pm 3,644,455 \mu \mathrm{m}^{3}$, which was higher than the high + lake treatment in experimental run 2, which reached a final average biomass of $799,579 \pm 36,716 \mu \mathrm{m}^{3}$ (Table 3). The treatments inoculated with the lowest cell density had the lowest final average biomass. The low + Bolds treatment in run one had a final average biomass of 9,169,159 $\pm 264,572 \mu \mathrm{m}^{3}$, which was lower than low + lake treatment final average biomass of 11,126,823.91 $\pm 1,455,382 \mu \mathrm{m}^{3}$ (Table 3). These were higher than the final biomass of the low treatments, low + lake and low + Bolds in experimental run two which had final biomasses of $213,252 \pm 2532 \mu \mathrm{m}^{3}$ and 194,811 \pm 2135 , respectively. The medium + lake treatment's final average biomass was $19,085,257 \pm 2,739,427 \mu \mathrm{m}^{3}$ in run one and $543,367 \pm 16,870 \mu \mathrm{m}^{3}$ in run 
two which was lower than the value in run one (Table 3). The medium treatments in both runs had a final average biomass higher than the both the low initial cell density treatments but lower than the high initial cell density treatments.

\section{Changes in Algal Growth Rates}

In experimental run one, between day zero and day three, the logarithmic growth rate of M. aeruginosa for each treatment was between 1.5 and 1.97 with the low + lake treatment having the highest growth rate, 1.97, and the med + lake having the lowest growth rate, 1.51 between the first three days (Figure 1). Microcystis aeruginosa growth rate of all the treatments decreased after day three. Microcystis aeruginosa in the high + lake treatment had its lowest growth rate between day 9 and 12 (Figure 2). Microcystis aeruginosa in the high + bolds treatment experienced its lowest growth rate between sampling day 12 and 15, and M. aeruginosa in the low + Bolds treatment experienced its lowest growth rate between sampling days 12 and 15 as well (Figure 2). No growth of M. aeruginosa was documented in the control group throughout the experiment.

In experimental run two, the growth rates of $M$. aeruginosa were highest in all treatments between day 0 and 3 as well, however the growth rates were lower than those observed in run 1 and ranged between 0.18 and 0.59 with the low + lake and low + bolds treatments having the highest growth rate between the first three days and the high + lake and high + bolds treatments had the lowest growth rate during the initial growth phase (Figure 3). This result is similar to that observed in run 1. Microcystis aeruginosa growth rate decreased in all three treatments after day 3 (Figure 4).

In experimental run 1 , during the initial growth period, between day 0 and day 3 , M. aeruginosa grew at same rate regardless of the initial cell density or the growth medium used. In this run, the growth rates of the low initial cell density treatments were always higher during this initial growth period compared to the high cell density treatments. In experimental run 2, during the initial growth period, growth rates were always higher in the low cell

Table 2. Initial $M$. aeruginosa cell densities and average $M$. aeruginosa cell density on day 15 for each treatment in run 1 and 2 of experiment. Initial density given in Table 1 . Mean density, cells $/ \mathrm{mL} \pm$ S.E.

\begin{tabular}{ccccc}
\hline \multirow{2}{*}{ Treatment } & \multicolumn{2}{c}{ Run 1 } & \multicolumn{2}{c}{ Run 2 } \\
\cline { 2 - 5 } & Initial Density & Final Mean Density & Initial Density & Final Mean Density \\
\hline Control & 0 & 0 & 0 & 0 \\
Low + Lake & 1069.00 & $495,893.81 \pm 45,864.80$ & 1064.36 & $9504.07 \pm 65.16$ \\
Med + Lake & 3208.00 & $850,580.62 \pm 86,330.10$ & 3345.15 & $24,216.5 \pm 434.10$ \\
High + Lake & 6417.00 & $1,836,257.31 \pm 114,851.06$ & 7204.93 & $35,635.19 \pm 944.73$ \\
Low + Bolds & 1069.00 & $408,645.72 \pm 8337.71$ & 1064.36 & $8682.22 \pm 95.15$ \\
High + Bolds & 6417.00 & $1,616,926.58 \pm 13,495.22$ & 7204.93 & $32,136.63 \pm 1328.77$ \\
\hline
\end{tabular}

Table 3. Initial and average M. aeruginosa biomass on day 15 for each treatment in run 1 and 2 of experiment. Mean biomass $\left(\mu \mathrm{m}^{3}\right) \pm$ S.E.

\begin{tabular}{|c|c|c|c|c|}
\hline \multirow{2}{*}{ Treatment } & \multicolumn{2}{|r|}{ Run 1} & \multicolumn{2}{|c|}{ Run 2} \\
\hline & Initial Biomass & Final Mean Biomass & Initial Biomass & Final Mean Biomass \\
\hline Control & 0 & 0 & 0 & 0 \\
\hline Low + Lake & $23,986.13$ & $11,126,823.91 \pm 840,265.24$ & $23,882.02$ & $213,251.54 \pm 1462.07$ \\
\hline Med + Lake & $71,980.84$ & $19,085,257.03 \pm 1,581,609.11$ & $75,058.19$ & $543,367.77 \pm 9740.21$ \\
\hline High + Lake & $143,984.11$ & $41,201,788.49 \pm 2,104,126.85$ & $161,663.62$ & $799,579.33 \pm 21,197.80$ \\
\hline Low + Bolds & $23,986.13$ & $9,169,158.71 \pm 152,750.81$ & $23,882.02$ & $194,811.01 \pm 1232.66$ \\
\hline High + Bolds & $143,984.11$ & $36,280,463.76 \pm 247,238.99$ & $161,663.62$ & $721,079.13 \pm 17,213.65$ \\
\hline
\end{tabular}




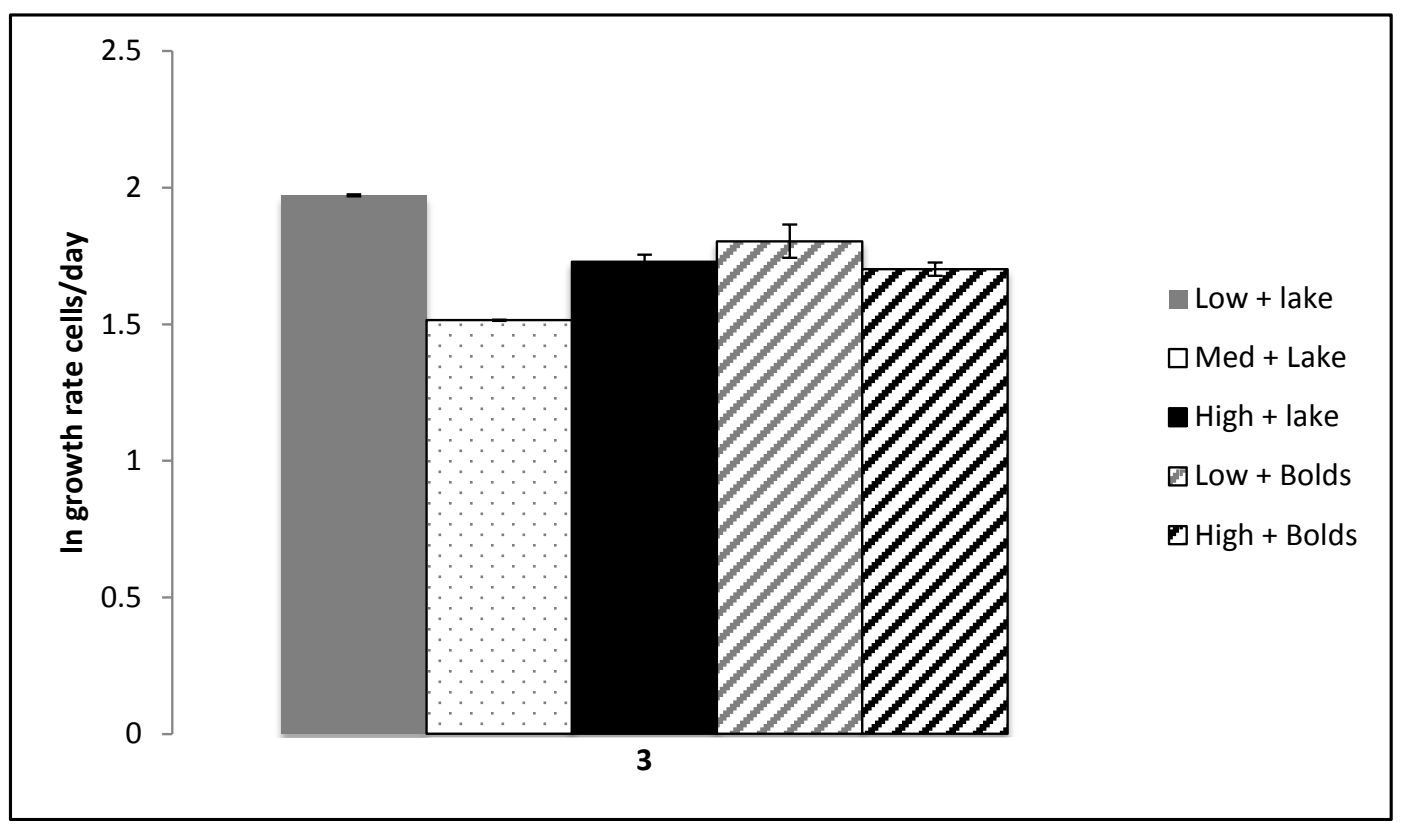

Figure 1. Logarithmic growth rate of $M$. aeruginosa between day 0 and day 3 for experimental run 1 . Mean \pm S.E.

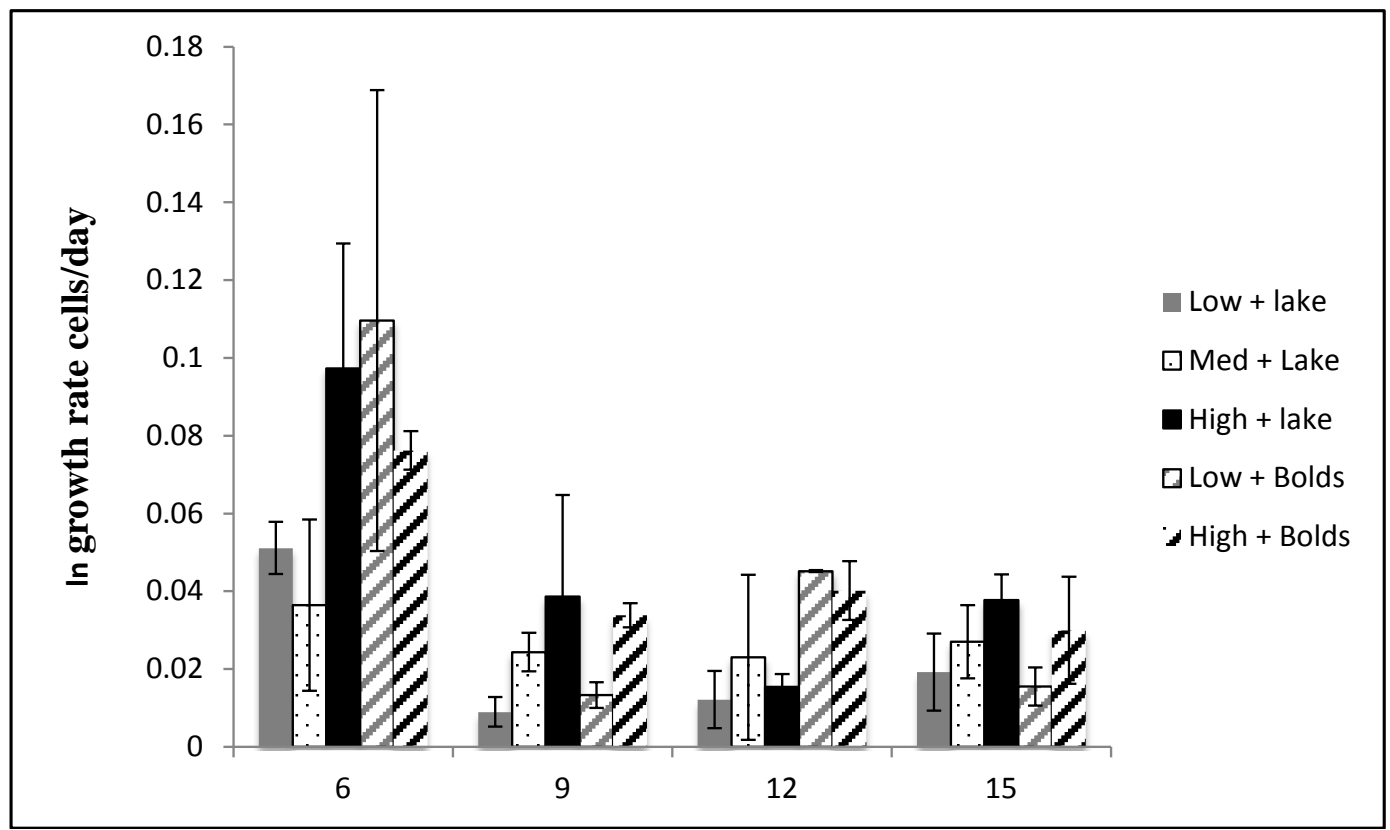

Figure 2. Logarithmic growth rate of $M$. aeruginosa between day 6 and day 15 for experimental run 1 . Mean \pm S.E.

density treatments. The high cell density treatments always had a significantly lower growth rate, regardless of medium, during the initial growth period compared to other treatments.

Initial cell density effect was compared to the final cell density in the three lake water treatments. There was a significant effect of initial cell density on final cell density at the $\mathrm{p}<0.05$ level for the three lake water treatments in experimental run 1 (ANOVA $F[2,6]=63.61, \mathrm{p}<0.001$ ) and experimental run two (ANOVA $F[2,6]=$ 316.27, $\mathrm{p}<0.001$ ). Higher cell initial cell densities cause M. aeruginosa to grow to higher final cell densities than those treatments with low initial cell densities. This result is true in both lake water and bolds medium. The effect of initial cell density was compared to the final cell density in the two bolds treatments (low + Bolds and high + Bolds). There was a significant effect of initial cell density on final cell density at the $p<0.05$ level for 


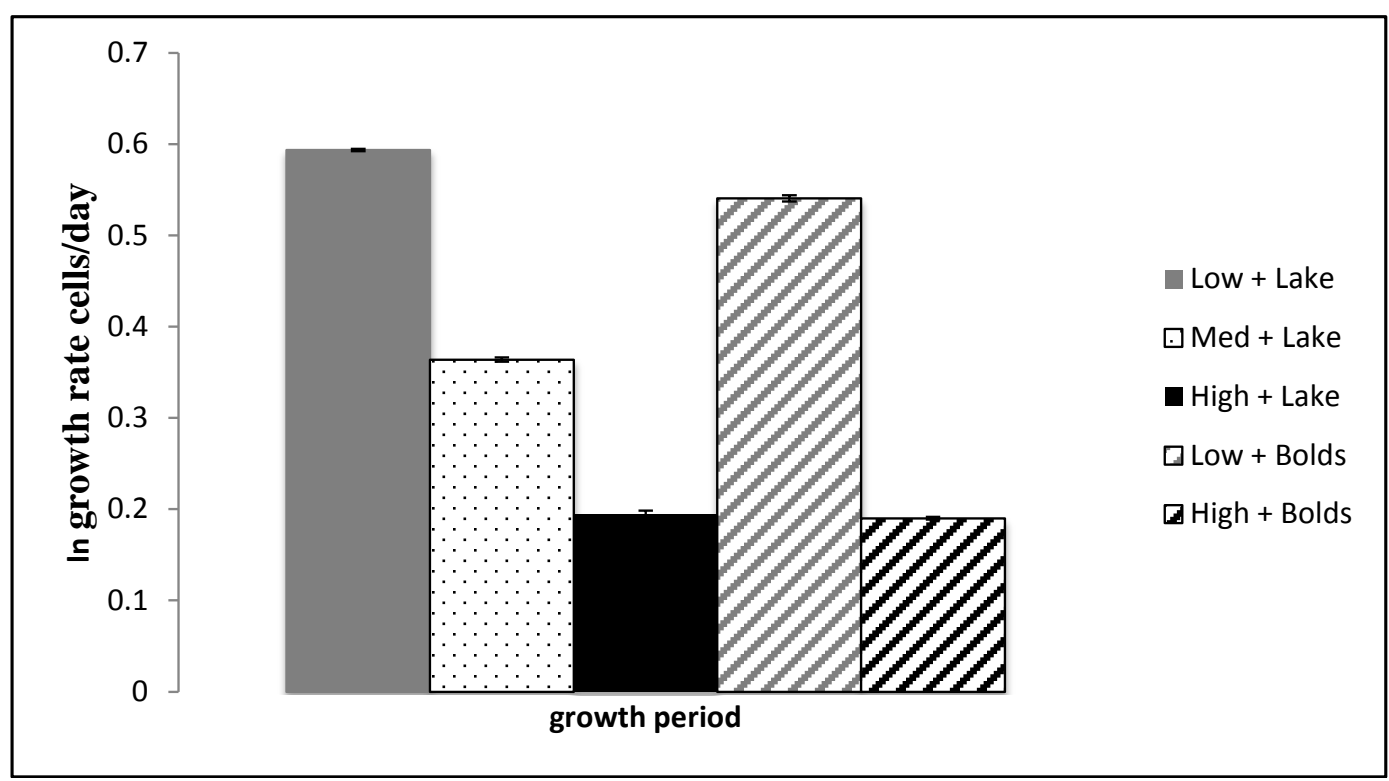

Figure 3. Logarithmic growth rate of $M$. aeruginosa between day 0 and day 3 for experimental run 2. Mean \pm S.E.

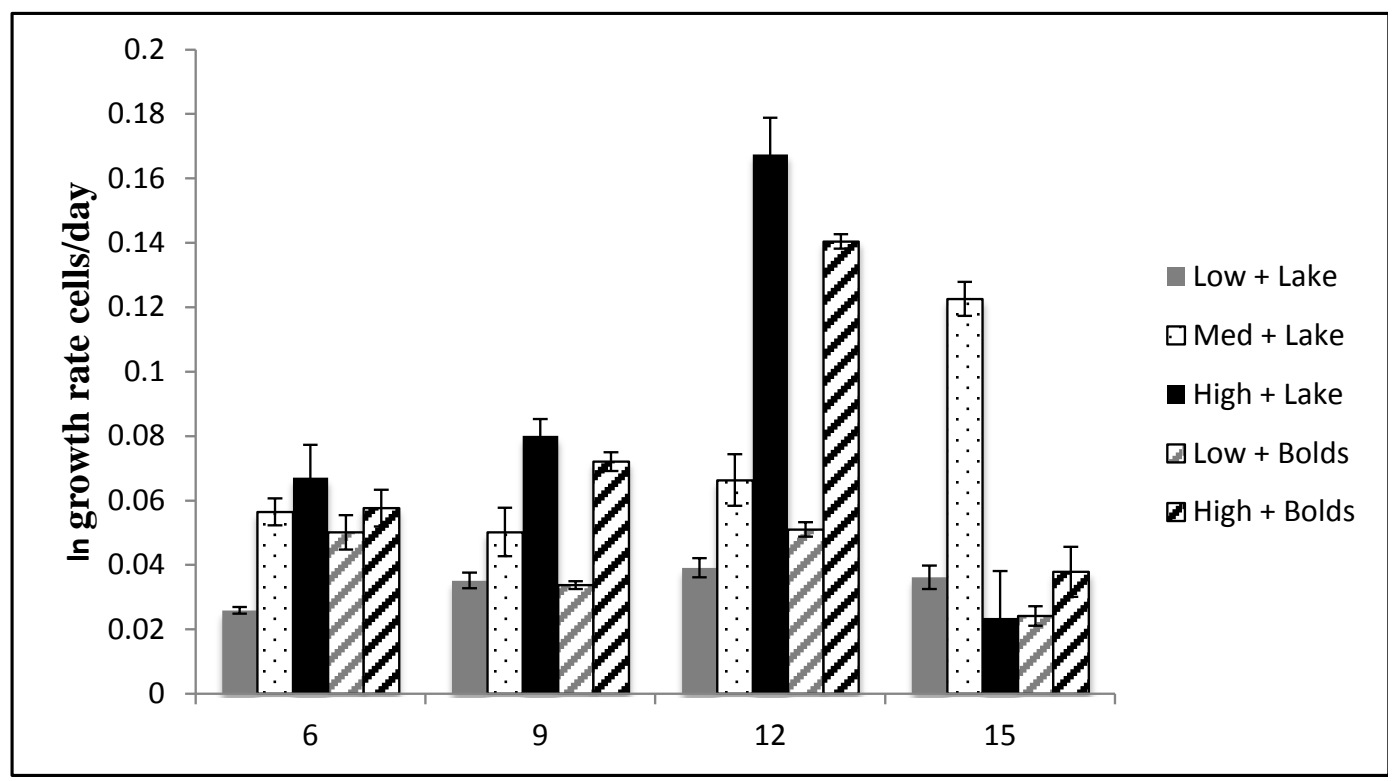

Figure 4. Logarithmic growth rate of $M$. aeruginosa between day 6 and day 15 for experimental run 2. Mean \pm S.E.

the two Bolds medium treatments in experimental run one (ANOVA F $[1,4]=5,801, \mathrm{p}=0.001$ ) and experimental run two (ANOVA F[1,4] = 619.94, $\mathrm{p}=0.001$ ).

The effect of growth medium was compared to final cell density. There was no significant effect of growth medium on the final cell density at the $\mathrm{p}<0.05$ level for the high + lake and high + Bolds treatments in experimental run one (ANOVA F $[1,4]=3.59, \mathrm{p}=0.13$ ) and experimental run two (ANOVA F[1,4] $=5.51, \mathrm{p}=0.079$ ). There was no significant effect of growth medium on final cell density at the $\mathrm{p}<0.05$ level for low + lake and low + Bolds treatments in experimental run one (ANOVA F[1,4] $=3.50, \mathrm{p}=0.13$ ) and experimental run two $($ ANOVA $F[1,4]=5.52, \mathrm{p}=0.11)$.

\section{Discussion}

This study showed that initial cell densities of M. aeruginosa will affect the cell density after a 15-day period 
regardless of the growth medium used. Lower initial cell densities of $M$. aeruginosa reached a significantly lower cell density after 15 days compared to the final cell densities of treatments inoculated with higher initial cell densities. Wood et al. [16] demonstrated a relationship between Microcystis cell density and microcystin synthesis indicating that an increase in Microcystis cell density increases the potential for a toxic algal blooms. Their study showed that an increase in Microcystis cell abundance to high cell densities greater than 3,000,000 cells $/ \mathrm{mL}$ cause an increase in associated microcystin quotas. The cell densities in the Wood et al. [16] experiment were much higher than the final cell densities in this experiment, but these results are significant when considering microcystin production during bloom formation of Microcystis cells.

The highest final cell density in run two of $M$. aeruginosa during this experiment was 35,635 $\pm 1636 \mathrm{cells} / \mathrm{mL}$. The cell densities of the two high initial cell density treatments and the medium + lake water treatment are classified into the moderate probability of health effects according to the guidelines provided by World Health Organization [19]. This is important in natural systems because a higher ambient cell density could have the potential to grow to significantly higher cell densities if conditions encourage $M$. aeruginosa proliferation. A change in conditions that lead to an increase in cell density of M. aeruginosa can cause more microcystin synthesis in these cells, thus leading to potentially toxic blooms [16].

The growth medium chosen had no effect on final cell densities under laboratory conditions. Final cell densities were slightly higher in the high initial cell density treatments, however these results were not significant indicating that growth medium has no significant effect. This indicates that $M$. aeruginosa will reach similar final cell densities regardless of the growth medium it is inoculated in under laboratory conditions. This result is important when trying to replicate bloom conditions in the laboratory. While studying microcystin production under laboratory conditions using axenic cultures has provided valuable information [20] [21] it has been shown that alterations occur in cyanobacteria that is maintained in culture for extended periods of times. These alterations include the loss of colonial morphology or the loss of toxin production [22] [23]. These results are significant because UTEX 2385 is a pure culture of M. aeruginosa that has been maintained in laboratory conditions for an extended period of time. The loss of some the important characters over time could have affected the final cell densities within this experiment creating difficulty when attempting to replicate bloom conditions.

The strain used in this experimental study, having been maintained in culture since 1954, may not have been exposed to various recent environmental cues as other populations, which could prevent the culture from expressing the typical traits of bloom forming M. aeruginosa. These cues include an increase in global temperature levels and an ever increasing incidence of eutrophication in waters across the globe. Microcystis aeruginosa exists in various different size and morphological variations thus making it difficult to find a strain accurately representing the natural population.

A study by Long et al. [24] showed that cellular microcystin content of nitrogen limited cells can be predicted from growth rate, with faster growing cells containing higher intracellular concentrations of microcystin. While this experiment was not conducted in nitrogen limited conditions it may have some implications in determining potential toxicity from growth rate. Faster growing cells may contain higher intracellular contents of microcystin than slower growing cells and in this experiment those treatments inoculated with higher initial cell densities had a higher growth rate indicating these cells could have more intracellular microcystin however this is unlikely due to the fact that the experiment was not done in nitrogen limited conditions and the same culture was used throughout the experiment.

There was a difference in the final cell densities reached in all treatments in experimental run one compared to those of experimental run two. The first run's highest cell density reached was 1,836,257 cells/mL, which would fall into the WHO guideline of a high probability of acute health effects. The second experiment run's highest density was 98 percent lower than this number at 35,635 cells/mL, which fell into the WHO guideline of a moderate probability of acute health effects [19]. This broad range of densities reached proves that it is difficult to replicate naturally occurring cell densities in the laboratory to develop sound management practices. Second experiment was done with water collected in fall and potentially chemical or other queues for faster growth were missing and the cells were preparing to overwinter.

The differences in densities between the two runs could be caused by a number of factors including difference in conditions in the lake water collected in March 2014 compared to that of September 2014. The present algal community placing competitive pressures on $M$. aeruginosa needs further investigation to determine any present taxa that be have been competing for resources in run two compared to that of run one. The high levels of other present taxa in Lake Sinclair including other cyanobacteria potentially played significant competitive pressures 
on M. aeruginosa. Filamentous cyanobacteria compete with $M$. aeruginosa and as $\mathrm{Li}$ and $\mathrm{Li}$ [25] found with Anabaena and Microcystis, the cyanobacteria with the higher initial cell density will outcompete the other. From an ecological perspective, keeping a high biodiversity of the phytoplankton community will ensure low abundance and density of $M$. aeruginosa, which reduces the potential for toxic blooms.

The presence of zooplankton and aquatic herbivores could have affected the final cell densities reached in each experimental run. Some aquatic herbivores, especially copepods like Bosmina, actually can facilitate cyanobacterial blooms by selectively grazing on non-cyanobacterial prey [26]. The high presence of zooplankton in March could explain the significantly higher cell densities in run one because cyanobacteria are often regarded as a poor food source for zooplankton [27] and thus feed any other available groups such as diatoms, Euglenoids, and green algae.

Multiple studies have indicated that Microcystis species proliferate in conditions of increased nitrogen; phosphorus or both [21] [28] [29] and this could have been the reason the final densities were much higher in run one compared to run two. Bolds medium has luxurious nutrient concentration and the documented similar growth in the lake water suggests high availability of nutrients.

\section{Changes in M. aeruginosa Growth Rates Based on Initial Cell Densities}

The growth rates in this experiment during the initial growth phase were similar to those growth rates observed by Davis et al. [30] for M. aeruginosa in field experiments. The growth rates they observed in elevated temperatures in four different systems were between 1.17 and 1.87. They observed the highest growth rates in elevated temperatures whereas the highest growth rates observed in this experiment were observed in the treatments with a lower initial cell density of $M$. aeruginosa. Temperature was not a measured factor in this experiment but previous research indicates that elevated temperatures can increase growth rates by 2-3 fold [30]. Davis et al. [30] did not observe increases in growth rate as a result of increases in nutrients and this result is important in our experimental results. This experiment was conducted in optimum nutrient conditions thus indicating that the high growth rates observed in the initial growth phase, followed by a decrease in growth rates after day 3 , were potentially being impacted by other environmental parameters.

In both experimental runs, there was a difference in carrying capacity between the treatments. In experimental run two there was no carrying capacity observed in the high treatments and medium treatments but for the low treatments carrying capacity was observed. This difference in carrying capacity could be a consequence of a number of factors. The treatments with high initial cell densities will grow at to a higher density quicker and will reach carrying capacity somewhere after day 15 because the resources will be limited. While it looks like carrying capacity has been reached in the low treatments, the low cell densities will grow slower over time but had this experiment been carried out for another 15 days it is very possible the low treatments would actually continue to grow and the high cell density treatments would reach carrying capacity.

Monitoring ambient $M$. aeruginosa cell densities could prove to be an important step in mitigating the potential of a toxic algal bloom as the results indicate that higher ambient cell densities proliferate to significantly higher cell densities. A continued increase of $M$. aeruginosa cells can have the potential to produce more microcystin as indicated by Wood et al. [16].

Suppressing M. aeruginosa cells and keeping this cyanobacterium at a low ambient density could help prevent the possibility of toxic cyanobacterial blooms in aquatic systems. Natural conditions have proven difficult to replicate in laboratory experiments and further research is needed to determine the effects of temperature, nutrients, and light on the growth and proliferation of $M$. aeruginosa in lake water in an attempt to gain sound scientific data to assist in the development of future management plans concerning freshwater algal blooms.

\section{Conclusion}

The occurrence of toxic algal blooms is increasing throughout aquatic habitats in the United States, and it is becoming urgent to develop a better understanding of the dynamics of cyanobacteria proliferation in aquatic habitats to develop solutions in preventing these occurrences. This research contributes to the understanding of toxic algal ecology and is the first experimental work in the southeastern United States providing evidence of differential toxic cyanobacteria growth under varying competitive interactions and density conditions. Allowing strong competitive interaction within algal community under low nutrient conditions and high algal diversity is proposed as a prevention of toxic algal bloom growth in natural habitats. 


\section{Acknowledgements}

This work was part of the first author's Masters graduate research at the Department of Biological and Environmental Sciences at Georgia College and State University. R. D. thanks members of Manoylov lab for helpful feedback in reviewing the manuscript.

\section{References}

[1] Paerl, H.W.R., Fulton, R., Moisander, P. and Dyble, J. (2001) Harmful Freshwater Algal Blooms, with an Emphasis on Cyanobacteria. The Scientific World, 1, 76-113. http://dx.doi.org/10.1100/tsw.2001.16

[2] Cloern. J. (2001) Our Evolving Conceptual Model of the Coastal Eutrophication Problem. Marine Ecology Progress Series, 210, 223-253. http://dx.doi.org/10.3354/meps210223

[3] Fogg, G.E. (1969) The Physiology of an Algal Nuisance. Proceedings of the Royal Society London [Biology], 173, 175-189. http://dx.doi.org/10.1098/rspb.1969.0045

[4] Reynolds, C.S. and Walsby, A.E. (1988) Water Blooms. Biological Review, 50, 437-481. http://dx.doi.org/10.1111/j.1469-185X.1975.tb01060.x

[5] Paerl, H.W. (1995) Nuisance Phytoplankton Blooms in Coastal, Estuarine, and Inland Waters. Limnology and Oceanography, 33, 823-847. http://dx.doi.org/10.4319/lo.1988.33.4_part_2.0823

[6] Paerl, H.W. and Tucker, C.S. (1995) Ecology of Blue-Green Algae in Aquaculture Ponds. Journal of the World Aquaculture Society, 26, 109-131. http://dx.doi.org/10.1111/j.1749-7345.1995.tb00235.x

[7] Paerl, H.W. and Otten, T.G. (2013) Blooms Bite the Hand that Feeds Them. Science, 342, 433-434. http://dx.doi.org/10.1126/science.1245276

[8] Sivonen, K, and Jones, G. (1999) Cyanobacterial Toxins. In: Chorus, I. and Bartram. J., Eds., Toxic Cyanobacteria in Water: A Guide to Public Health Significance, Monitoring, and Management, WHO \& E\&FN Spon, London, 41-111.

[9] Bartram, J., Carmichael, W.W., Chorus, I., Jones, G. and Skulberg, O.M. (1999) Introduction. In: Chorus, I. and Bartram. J., Eds., Toxic Cyanobacteria in Water: A Guide to Public Health Significance, Monitoring, and Management, WHO \& E\&FN Spon, London, 1-14.

[10] Chorus, I. (2001) Introduction: Cyanotoxins-Research for Environmental Safety and Human Health. In: Chorus, I., Ed., Cyanotoxins-Occurrence, Causes, Consequences, Springer-Verlag, Berlin, 1-4. http://dx.doi.org/10.1007/978-3-642-59514-1_1

[11] Hawkins, P.R., Runnegar, M.T.C., Jackson, A.R.B. and Falconer, I.R. (1985) Severe Hepatotoxicity Caused by the Tropical Cyanobacterium [Blue-Green Alga] Cylindrospermopsis raciborskii (Woloszynska) Seenaya and Subba Raju Isolated from a Domestic Water Supply Reservoir. Applied Environmental Microbiology, 50, 1292-1295.

[12] Codd, G.A. and Bell, S.G. (1996) The Occurrence And fate of Blue-Green Algal Toxins in Freshwaters. R \& D Report 29, National Rivers Authority, London.

[13] Carmichael, W.W. (1997) The Cyanotoxins. Advanced Botanical Research, 27, 211-256. http://dx.doi.org/10.1016/S0065-2296(08)60282-7

[14] Wang. X., Qin, B., Gao, G. and Paerl, H.W. (2010) Nutrient Enrichment and Selective Predation by Zooplankton Promote Microcystis [Cyanobacteria] Bloom Formation. Journal of Plankton Research, 32, 457-470. http://dx.doi.org/10.1093/plankt/fbp143

[15] Otsuka, S., Suda, S., Li, R., Watanabe, M., Oyaizu, H., Matsumoto, S. and Watanabe, M.M. (1999) Phylogenetic Relationships between Toxic and Non-Toxic Strains of the Genus Microcystis Based on 16S and 23S Internal Transcribed Spacer Sequence. FEMS Microbiology Letters, 172, 15-21. http://dx.doi.org/10.1111/j.1574-6968.1999.tb13443.x

[16] Wood, S.A., Dietrich, D.R., Cary, C. and Hamilton, D.P. (2012) Increasing Microcystis Cell Density Enhances Microcystin Synthesis: A Mesocosm Study. Inland Waters, 2, 17-22. http://dx.doi.org/10.5268/IW-2.1.424

[17] Hildebrand, H., Durselen, C., Pollingher, U. and Zohary, T. (1999) Biovolume Calculation for Pelagic and Benthic Microalgae. Journal of Phycology, 35, 403-424. http://dx.doi.org/10.1046/j.1529-8817.1999.3520403.x

[18] Cole, G.T. and Wynne, M.J. (1974) Endocytosis of Microcystis aeruginosa by Ochromonas Danica. Journal of Phycology, 25, 15-26. http://dx.doi.org/10.1111/j.1529-8817.1974.tb02732.x

[19] World Health Organization (1998) Guidance for Drinking Water Quality, Vol. 2. Health Criteria and Other Supporting Information. 2nd Edition, World Health Organization, Geneva.

[20] Orr, P.T. and Jones, G.J. (1998) Relationship between Microcystin Production and Cell Division Rates in Nitrogen-Limited Microcystis aeruginosa Cultures. Limnology and Oceanography, 43, 1604-1614. http://dx.doi.org/10.4319/lo.1998.43.7.1604 
[21] Oh, H.M., Lee, S.J., Jang, M.H. and Yoon, B.D. (2000) Microcystin Production by Microcystis aeruginosa in a Phosphorous Limited Chemostat. Applied and Environmental Microbiology, 66, 176-179. http://dx.doi.org/10.1128/AEM.66.1.176-179.2000

[22] Schatz, D., Karen, Y., Hadas, O., Carmeli, S., Sukenik, A. and Kaplan, A. (2005) Ecological Implications of the Emergence of Non-Toxic Subcultures from Toxic Microcystis Strains. Environmental Microbiology, 7, 798-805. http://dx.doi.org/10.1111/j.1462-2920.2005.00752.X

[23] Zhang, M., Kong, F., Tan, X., Yang, Z., Cao, H. and Xing, P. (2007) Biochemical, Morphological, and Genetic Variations in Microcystis aeruginosa Due to Colony Disaggregation. World Journal of Microbiology and Biotechnology, 23, 663-670. http://dx.doi.org/10.1007/s11274-006-9280-8

[24] Long, B.M., Jones, G.J. and Orr, P.T. (2001) Cellular Microcystin Content in N-Limited Microcystis aeruginosa Can Be Predicted from Growth Rate. Applied and Environmental Microbiology, 67, 278-283. http://dx.doi.org/10.1128/AEM.67.1.278-283.2001

[25] Li, Y. and Li, D. (2012) Competition between Toxic Microcystis aeruginosa and Nontoxic Microcystis wesenbergii with Anabaena PCC7120. Journal of Applied Phycology, 24, 69-78. http://dx.doi.org/10.1007/s10811-010-9648-x

[26] Hong, Y., Burford, M.A., Ralph, P.J., Udy, J.W. and Doblin, M.A. (2013) The Cyanobacterium Cylindrospermopsis raciborskii Is Facilitated by Copepod Selective Grazing. Harmful Algae, 29, 14-21. http://dx.doi.org/10.1016/j.hal.2013.07.003

[27] Jiang, X., Yang, W., Xiang, X., Niu, Y., Chen, L. and Zhang, J. (2014) Cyanobacteria Alter Competitive Outcomes between Daphnia and Bosmina in Dependence on Environmental Conditions. Fundamental and Applied Limnology, 184, 11-12. http://dx.doi.org/10.1127/1863-9135/2014/0580

[28] Watanbe, M.F. and Oishi, S. (1985) Effects of Environmental Factors on Toxicity of a Cyanobacterium (Microcystis aeruginosa) under Culture Conditions. Applied and Environmental Microbiology, 49, 1342-1344.

[29] Codd, G.A. and Poon, G.K. (1988) Cyanobacteria Toxins. In: Rogers, L.J. and Gallon, J.R., Eds., Biochemistry of the Algae and Cyanobacteria, Clarendon Press, Oxford, 283-296.

[30] Davis, T.W., Berry, D.L., Boyer, G.L. and Gobler, C.J. (2009) The Effects of Temperature and Nutrients on the Growth and Dynamics of Toxic and Non-Toxic Strains of Microcystis during Cyanobacteria Blooms. Harmful Algae, 8, 715-725. http://dx.doi.org/10.1016/j.hal.2009.02.004

\section{Submit or recommend next manuscript to SCIRP and we will provide best service for you:}

Accepting pre-submission inquiries through Email, Facebook, LinkedIn, Twitter, etc.

A wide selection of journals (inclusive of 9 subjects, more than 200 journals)

Providing 24-hour high-quality service

User-friendly online submission system

Fair and swift peer-review system

Efficient typesetting and proofreading procedure

Display of the result of downloads and visits, as well as the number of cited articles

Maximum dissemination of your research work

Submit your manuscript at: http://papersubmission.scirp.org/ 